\title{
Financial Feasibility of Broiler Production in Case of Non Contract and Contract Farms
}

\author{
Mohan Kumar, A.*1 and S.R. Torane ${ }^{2}$ \\ ${ }^{1}$ Department of Agricultural Economics, College of Agriculture, Dr. B S K K V, Dapoli, Maharashtra, India \\ ${ }^{2}$ Deputy Director of Research and PME Cell ( I/c), Dr. Balasaheb Sawant Konkan Krishi Vidyapeeth, Dapoli, Maharashtra, India \\ "Corresponding author: mohanghalli28@gmail.com
}

\begin{abstract}
An attempt was made to explore the financial feasibility of broiler poultry production in Chikkaballapur district of Karnataka. The objective of the study was to work out cost and returns in broiler production and to assess the financial feasibility of broiler production. The data was collected from 90 broiler farms consists of both non contract and contract farms. In the study area, the average fixed capital investment made per bird was ₹ 213.74 and ₹ 151.51 in non contract and contract farms respectively. Cost of production and net returns per bird were ₹ 123.16 and ₹ 18.44 respectively in case of non contract farms against $₹ 11.02$ and ₹ 4.62 in contract farms. In the study area, number of birds to be raised annually to cover the cost of production in non contract and contract farms was found to be 13118 and 26692. The feasibility study shows that, the investment in non contract broiler farms was economically feasible with NPV of ₹ 2892260 , BC ratio of 1.14 and IRR 49.53 per cent indicating more returns per rupee invested. Conversely, investment in contract broiler farms was just marginally feasible with NPV of ₹ 28928, BC Ratio of 1.41 and IRR 16.39 percent.

Highlights

0 Dissimilar operation pattern was found between non contract and contract farms, as farm owners were compensated only with rearing charges and take away major portion of the returns.

( $)$ Non contract farms were found to be more financially feasible than contract farms.
\end{abstract}

Keywords: Flock size, Depreciation, Mortality, Sanitation, Payback period, Break even analysis, Internal rate of returns

Indian Poultry Industry is 5,000 years old whereas the poultry sector in India has undergone a paradigm shift in structure and operation. A significant feature of India's poultry industry has been its transformation from a mere backyard activity into a major commercial activity in just about four decades. This transformation has involved sizeable investments in breeding, hatching, rearing and processing. Indian broiler production experienced a growth rate of 8 per cent during the last four decades (Chatterjee and Rajkumar, 2015). Whereas in the year 2016-17 total production of broiler meat was 3.46 million tonnes with export potential of 5304.39 million (APEDA, 2017). Poultry farming assumes special significance in the Chikkaballapur district of Karnataka due to increasing industrialization, increasing population growth, changing food habit, urbanization and nearness to Bengaluru city, increased per capita income and awareness about nutrition etc. are contributing towards rising demand of poultry products. Therefore present study was undertaken with the objectives of working out cost and returns and assessing financial feasibility of broiler production. The results obtained from the present study will be helpful to Broiler farm owners to provide some guidelines regarding capital investment, cost and returns, productivity and profitability status of Broiler farms in general and study area in particular. The findings of the study will also helpful to those who are willing to undertake broiler poultry farming as an occupation. 


\section{MATERIALS AND METHODS}

The present study was undertaken to look in to the investment pattern, costs and returns structure, production efficiency and economic viability of non contract and contract poultry farms. Four-stage random sampling technique with region as first, district as second, taluk as third and the ultimate respondents as fourth stage sampling unit was adopted.

A sample of 90 broiler farms comprising 9.4 lakh birds was selected from three taluks (30 each) of Chikkaballapura district randomly in such a way that each category consists of 10 samples including non contract and contract farms. The primary data were collected by personal interview method using pre designed schedules. To study the financial feasibility of poultry enterprise, undiscounted measure payback period and discounted measures like net present value, benefit-cost ratio and internal rate of return were calculated using standard procedures.

\section{RESULTS AND DISCUSSION}

Average initial fixed capital investment made in the establishment of broiler poultry units was ₹ 2462110 in non-contract farms with average flock size of 11519 birds as against ₹ 934344 in contract farms with average flock size of 6167 birds. Out of the total initial capital investment 71.36 percent accounts for construction of broiler house and 19.19 for equipment and machinery. Per bird fixed capital investment was found to be more in non-contract farms ₹ 213.74 compared to ₹ 151.51 in contract farms due to absence of expenditure on store house, advanced automated equipment and machinery. The results obtained were contrary with the study conducted by Singh et al. (2010) for non contract farms whereas similar results were observed by Patil et al. (2017) for fixed capital investment per bird in contract farms.

Cost and returns pattern of non contract and contract farms was found to be dissimilar; therefore the results were presented separately.

\section{Cost and returns in non contract farms}

The average total cost of production per annum was found to be ₹ 7187392. Out of the total cost, variable cost and fixed cost accounts for 95.15 per cent and 4.85 per cent respectively. Among total cost, cost of feed accounts for 62.74 percent, cost of chicks 21.03 per cent were contributing major share followed by interest on fixed capital $(2.74 \%)$, cost of mortality $(2.66 \%)$, wages of labour $(2.40 \%)$ and cost of litter material $(2.35 \%)$ and all other remaining costs accounts for 6.03 per cent. Similar results were observed in the study conducted by Pawariya and Jheeba (2015) where cost of feed and cost of chicks were the major items of total cost.

The average cost of production per bird in non contract farms is presented in Table 1. It is seen from the table 1 that, at overall level the total cost of broiler production per bird was found to be ₹ 123.11. Again it was highest in small ₹ 133.99 followed by medium ₹ 120.56 and large groups $₹ 115.15$ respectively. Similar results were observed by Balamurugan and Manoharan (2013) (Table 1 and 2).

It was observed from the table 1 and table 2, that the total cost of production per bird and per $\mathrm{kg}$ of live weight decreased as size of broiler farm increased, indicating economies of scale and reason for such a difference in per bird cost was due to lesser feed cost in medium and large size broiler poultry units, as majority of farmers procure poultry feed ingredients such as maize, soya, groundnut and sunflower cake from different sources and prepare own feed in the farms itself rather than buying readymade feed which costs comparatively more.

Returns obtained from broiler production in non contract farms are presented in Table 3. The average annual gross returns obtained per farm was Rs.8467177. At the overall level out of total gross returns obtained 97.67 per cent from sale of broiler birds, 2.14 per cent from sale of poultry manure and 0.19 per cent from sale of empty gunny bags and carton boxes. Similar results were observed by the Shaikh and Zala (2011). Average returns obtained per bird from sale of broiler birds, sale of poultry manure and sale of empty bags and carton boxes from different groups at overall level was ₹ 141.75. Among the groups it was ₹ 144.02, ₹ 142.16 and $₹ 138.94$ in small, medium and large groups, respectively (Table 3$)$. Similar results were observed by Borah and Halim (2017).

Average net returns obtained from broiler poultry production was ₹ 1318094 . It was ₹ 262470 , ₹ 979414 
Financial Feasibility of Broiler Production in Case of Non Contract and Contract Farms $\mathcal{C P}$

Table 1: Cost of production per bird in non contract farms

\begin{tabular}{|c|c|c|c|c|c|c|}
\hline S1. No. & Particulars & Small & Medium & Large & \multicolumn{2}{|c|}{ Overall } \\
\hline (A) & Variable cost & & & & & \\
\hline 1 & Wages of labour & 3.59 & 4.09 & 2.15 & 3.30 & $(2.68)$ \\
\hline 2 & Cost of one day old chicks & 26.00 & 25.00 & 25.00 & 25.33 & (20.57) \\
\hline 3 & Cost of feed & 89.31 & 72.84 & 72.18 & 78.12 & $(63.46)$ \\
\hline 4 & Cost of Litter material & 2.98 & 3.24 & 2.56 & 2.94 & $(2.39)$ \\
\hline 5 & Electricity charges & 0.30 & 0.57 & 0.47 & 0.44 & $(0.36)$ \\
\hline \multirow[t]{2}{*}{6} & Medical/vaccines expenses & 1.65 & 2.12 & 1.66 & 1.82 & $(1.47)$ \\
\hline & Miscellaneous items expenditure & & & & & \\
\hline \multirow[t]{2}{*}{7} & a) Expenses on sanitation & 0.43 & 0.82 & 0.55 & 0.60 & $(0.49)$ \\
\hline & b) cost of coal & 1.70 & 2.22 & 1.69 & 1.83 & $(1.48)$ \\
\hline \multirow[t]{2}{*}{8} & Cost of mortality & 2.94 & 3.37 & 3.15 & 3.16 & $(2.57)$ \\
\hline & Total variable cost (A) & 128.90 & 114.27 & 109.41 & 117.54 & $(95.47)$ \\
\hline (B) & Fixed cost & & & & & \\
\hline 1 & Rental value of owned land & 0.49 & 0.48 & 0.50 & 0.49 & $(0.40)$ \\
\hline 2 & Depreciation on fixed capital assets & 1.76 & 2.20 & 2.02 & 2.00 & $(1.62)$ \\
\hline \multirow[t]{3}{*}{3} & $\begin{array}{l}\text { Interest on fixed capital ( } 08 \% \text { of initial } \\
\text { capital investment) }\end{array}$ & 2.84 & 3.61 & 3.22 & 3.08 & $(2.51)$ \\
\hline & Total fixed cost (B) & 5.09 & 6.29 & 5.74 & 5.57 & $(4.53)$ \\
\hline & Total cost $(\mathrm{A}+\mathrm{B})$ & 133.99 & 120.56 & 115.15 & 123.11 & $(100.00)$ \\
\hline
\end{tabular}

(Figures in parentheses represent percentage to total cost)

Table 2: Cost of production per kg of live weight in non contract farms

\begin{tabular}{clcccc}
\hline S1. No. & \multicolumn{1}{c}{ Particulars } & Small & Medium & Large & Overall \\
\hline 1 & Average live weight per bird $(\mathrm{kg})$ & 2.00 & 2.03 & 2.05 & 2.03 \\
2 & Total cost of rearing per bird (₹) & 133.99 & 120.56 & 115.15 & 123.16 \\
3 & Cost of production per kg of live weight $(₹)$ & 66.99 & 59.68 & 56.17 & 60.67 \\
\hline
\end{tabular}

Table 3: Gross returns from broiler production in non contract farms

\begin{tabular}{clccccc}
\hline S1. No. & \multicolumn{1}{c}{ Particulars } & Small & Medium & Large & \multicolumn{2}{c}{ Overall } \\
\hline (A) & Annual gross returns per farm & & & & & \\
\hline 1 & Sale of broiler poultry birds & 3681656 & 6297872 & 15201355 & 8269968 & $(97.67)$ \\
2 & Sale of poultry Manure & 79204 & 136764 & 337077 & 181566 & $(2.14)$ \\
3 & Sale of empty bags and carton boxes & 12536 & 16139 & 18345 & 15643 & $(0.19)$ \\
& Gross income & 3773396 & 6450775 & 15556776 & 8467177 & $\mathbf{( 1 0 0 . 0 0 )}$ \\
\hline (B) & Gross returns per bird & & & & & \\
\hline 1 & Sale of broiler poultry birds & 140.52 & 138.79 & 135.76 & 138.40 & \\
2 & Sale of poultry Manure & 3.02 & 3.01 & 3.01 & 3.01 & \\
3 & Sale of empty bags and Carton boxes & 0.48 & 0.36 & 0.17 & 0.34 & \\
& Gross income & 144.02 & 142.16 & 138.94 & 141.75 & \\
\hline
\end{tabular}

(Figures in parentheses represent percentage to total). 
C) Kumar and Torane

and ₹ 2391459 in small, medium and large farms respectively. At overall level per bird net returns obtained was ₹ 18.44. Again it was ₹ 10.01, ₹ 21.58 and ₹ 23.83 in small, medium and large groups, respectively (Table 4 ).

Table 4: Net returns from different group of non contract broiler farms

\begin{tabular}{|c|c|c|c|c|c|}
\hline $\begin{array}{l}\text { Sl. } \\
\text { No. }\end{array}$ & Particulars & Small & Medium & Large & Overall \\
\hline \multirow[t]{4}{*}{ I) } & \multicolumn{5}{|c|}{ Per farm (Annually) } \\
\hline & $\begin{array}{c}\text { Gross } \\
\text { returns }\end{array}$ & 3773396 & 6450871 & 15556776 & 8653408 \\
\hline & Total cost & 3510926 & 5471367 & 13165317 & 7335314 \\
\hline & Net returns & 262470 & 979414 & 2391459 & 1318094 \\
\hline \multirow[t]{4}{*}{ II) } & Per bird & & & & \\
\hline & Gross returns & 144.01 & 142.15 & 138.94 & 141.74 \\
\hline & Total cost & 134.00 & 120.57 & 115.11 & 123.30 \\
\hline & Net returns & 10.01 & 21.58 & 23.83 & 18.44 \\
\hline
\end{tabular}

It was concluded that, the net returns per bird from the broiler production in non contract farms was increased as size of broiler farm increases due to decreased total cost and distribution of fixed cost over large output.

\section{Cost and returns in contract farms}

The cost returns in contract broiler production was presented in Table 5. Average initial capital investment made on capital assets to start contract broiler farms with average flock size of 6167 birds was found to be ₹ 934344 .

Average number of birds reared per annum in the contract broiler farms was 35645 . The total cost of production in contract farms was found to be ₹ 392718 per annum and ₹ 11.02 per bird. Whereas cost of production per $\mathrm{kg}$ of live weight was found to be ₹ 2.38. Out of total cost incurred variable cost and fixed cost accounts for 66.99 per cent and 33.01 per cent respectively. Among the total cost, cost of litter material $(25.43 \%)$, interest on fixed capital investment (19.03\%), wages of labour (17.68\%) and cost of coal (14.59\%), depreciation on building machinery and equipment $(12.15 \%)$ were contributing major share followed by expenses on sanitation $(4.02 \%)$, Electric charges $(2.39 \%)$ and rental value of owned land accounts for 1.83 per cent (Table 5).
Table 5: Cost of broiler production in contract farms

\begin{tabular}{|c|c|c|c|c|}
\hline $\begin{array}{l}\text { Sl. } \\
\text { No. }\end{array}$ & Particulars & $\begin{array}{l}\text { Per farm } \\
\text { (Annual) }\end{array}$ & & $\begin{array}{l}\text { Per } \\
\text { bird }\end{array}$ \\
\hline (A) & \multicolumn{4}{|c|}{ Variable cost incurred by farmer } \\
\hline 1 & Wages of labour & 69458 & $(17.68)$ & 1.95 \\
\hline 2 & Cost of Litter material & 99867 & $(25.43)$ & 2.80 \\
\hline 3 & Electricity charges & 9375 & $(2.39)$ & 0.26 \\
\hline \multirow[t]{3}{*}{4} & Miscellaneous & & & \\
\hline & a) Expenses on sanitation & 15785 & $(4.02)$ & 0.44 \\
\hline & b) cost of coal & 57314 & $(14.59)$ & 1.61 \\
\hline \multirow[t]{2}{*}{5} & Cost of Mortality & 11283 & $(2.87)$ & 0.32 \\
\hline & Total variable cost (A) & 263082 & $(66.99)$ & 7.38 \\
\hline (B) & Fixed cost & & & \\
\hline 1 & $\begin{array}{l}\text { Depreciation on } \\
\text { buildings, equipment and } \\
\text { machinery }\end{array}$ & 47704 & $(12.15)$ & 1.34 \\
\hline 2 & $\begin{array}{l}\text { Rental value of owned } \\
\text { land }\end{array}$ & 7184 & $(1.83)$ & 0.20 \\
\hline \multirow[t]{3}{*}{3} & $\begin{array}{l}\text { Interest on fixed } \\
\text { capital (10\% to fixed } \\
\text { investment) }\end{array}$ & 74748 & $(19.03)$ & 2.10 \\
\hline & Total fixed cost (B) & 129636 & $(33.01)$ & 3.64 \\
\hline & Total cost $(A+B)$ & 392718 & $(100.00)$ & 11.02 \\
\hline
\end{tabular}

(Figures in parentheses represent percentage to total cost).

Table 6: Gross returns from broiler production in contract farms

\begin{tabular}{rrrrr}
\hline $\begin{array}{c}\text { Sl. } \\
\text { No. }\end{array}$ & $\begin{array}{c}\text { Particulars } \\
\text { (Annual) }\end{array}$ & & $\begin{array}{c}\text { Per } \\
\text { bird }\end{array}$ \\
\hline 1 & $\begin{array}{l}\text { Sale of broiler poultry } \\
\text { birds }\end{array}$ & 430610 & $(77.22)$ & 12.49 \\
2 & $\begin{array}{l}\text { Sale of poultry Manure } \\
\text { Sale of empty bags and }\end{array}$ & 108774 & $(19.51)$ & 3.15 \\
& $\begin{array}{l}\text { Salon boxes } \\
\text { carton bes }\end{array}$ & $(3.27)$ & 0.53 \\
& Gross income & 557614 & $(100.0)$ & 16.17 \\
\hline
\end{tabular}

(Figures in parentheses represent percentage to total gross income).

The average annual gross returns obtained per farm in contract group was ₹ 557614. Out of total gross returns, 77.22 per cent were derived from sale of broiler birds, 19.51 per cent from sale of poultry manure and 3.27 per cent from sale of empty feed bags and carton boxes. The total gross income obtained per bird was ₹ 16.17. Net returns per bird and per $\mathrm{kg}$ of live weight from the broiler production in contract farms were found to be ₹ 4.62 and ₹ 2.25 respectively(Table 6 and 7). 
Table 7: Net returns from broiler production in contract farms

\begin{tabular}{cccc}
\hline $\begin{array}{r}\text { Sl. } \\
\text { No. }\end{array}$ & Particulars & $\begin{array}{c}\text { Per farm } \\
\text { (Annually) }\end{array}$ & Per bird \\
\hline 1 & Gross returns & 557614 & 15.64 \\
2 & Total cost & 392718 & 11.02 \\
3 & Net returns & 164896 & 4.62 \\
\hline
\end{tabular}

It was observed that the net returns obtained from contract broiler poultry units were found to be lower than non contract broiler poultry units. It may be due to fact that being a prime contributor of variable cost, major share of total income obtained through sale of broiler birds were taken away by contracting company and on the basis of terms and conditions of contract (Kumar and Panigraphy, 2016). This could be the reason due to which contract broiler farming remains uneconomic business when compared to non contract broiler poultry farming. However some farmers who lack adequate funds to meet the huge variable cost were doing contract poultry farming in order to cover fixed cost and to earn some small profit margin over variable cost which was incurred by second party in contract rather than leaving the poultry sheds empty.

\section{Break even analysis}

The minimum number of birds to be raised per batch at average productivity to cover the cost incurred should be 2452 and 4618 in non-contract and contract farms respectively. In case of noncontract it was 1954, 2125 and 4286 birds on small, medium and large groups respectively. The obtained results were found contrary with the study conducted by Shaikh and Zala (2005) where break even output in terms of birds was 1531, 2611 and 10437 in small, medium and large farms respectively. Further margin of safety was found to be more in non contract farms $(78.24 \%)$ indicating safer compared to contract farms (22.61\%) (Table 8$)$.

\section{Financial Feasibility}

The contract broiler farms have taken longer time (5.67 years) to cover up their initial capital investment as compared to non-contract farms (2.51 years). Net present value at overall level was ₹ 2892260 in non-contract farms against ₹ 28928 in contract farms. Benefit cost ratio of the non contract farms at the overall level was 1.14 and 1.41 in contract farms. Internal rate of returns at overall level was 49.53 per cent in non-contract farms and 16.39 percent in contact farms which is just above the opportunity cost of capital (15\%) indicating investment in contract broiler poultry is comparatively less economically feasible(Table 9). Similar results were observed by Singh et al (2010) and Shaikh and Zala (2005) for the financial feasibility.

It was observed that, in case of non-contract farms the payback period was less, Net present value is

Table 8: Break even output in broiler production

\begin{tabular}{clccccc}
\hline \multirow{2}{*}{ S1. No. } & \multicolumn{1}{c}{ Particulars } & Small & Medium & Large & Overall & Contract \\
\hline 1 & $\begin{array}{l}\text { Actual number of birds reared } \\
\text { per batch }\end{array}$ & 4468 & 8336 & 21054 & 11109 & 5967 \\
2 & $\begin{array}{l}\text { Break even output in terms of } \\
\text { birds reared per batch }\end{array}$ & 1954 & 2125 & 4286 & 2452 & 4618 \\
3 & Margin of safety (\%) & 56.26 & 74.51 & 79.64 & 78.24 & 22.61 \\
\hline
\end{tabular}

Table 9: Financial feasibility in broiler production

\begin{tabular}{ccccccc}
\hline \multirow{2}{*}{ S1. No. } & \multirow{2}{*}{ Parameters } & \multicolumn{4}{c}{ Non-contract } & \multirow{2}{*}{ Contract } \\
\cline { 3 - 6 } & Small & Medium & Large & Overall & \\
\hline 1 & Pay Back Period (years) & 3.54 & 2.09 & 1.89 & 2.51 & 5.67 \\
2 & Net Present Value (₹) & 356954 & 2118754 & 6378563 & 2892260 & 28928 \\
3 & Benefit Cost Ratio & 1.07 & 1.16 & 1.18 & 1.14 & 1.41 \\
4 & Internal Rate of Return (\%) & 29.07 & 53.64 & 66.41 & 49.53 & 16.39 \\
5 & Profitability Index & 0.38 & 1.03 & 1.41 & 0.94 & 0.03 \\
\hline
\end{tabular}




\section{C) Kumar and Torane}

positive, Benefit cost ratio is more than one and Internal rate of returns were higher than prevailing rate of interest. The broiler poultry business is economically feasible. However, in case of contract farms payback period is higher, Net present value is positive, Benefit cost ratio is more than one and it is at par to prevailing rate of interest which can be considered as a low (16.39\%). Hence, the contract farms were found to be comparatively less economical than non contract farms.

\section{CONCLUSION}

Broiler production farms in the study area were basically categorized in to two types' viz. non contract and contract farms. It was found that there was dissimilar operational pattern among the categories. It was revealed from the study that non contract farms were more financially feasible than contract farms. However, broiler production in contract farms is also feasible to those farmers who lack adequate funds to meet huge variable cost. Contract farmers were able to derive descent returns for their investment. Therefore, for those who lack adequate funds, it is advisable to go for the contract broiler production rather than leaving the broiler farms empty.

\section{ACKNOWLEDGEMENTS}

The authors are grateful to the broiler farmers of Chikkaballapur district, Deputy Director, Department of Animal Husbandry and Veterinary Services, Chikkaballapur district and Raju, Line supervisor, Venkateshwara Hatcheries Ltd., Chikkaballapur.

\section{REFERENCES}

APEDA. 2017. http://agriexchange.apeda.gov.in/product_ profile/exp_f_india.aspx?.PDF. Accessed 18 December 2017.

Balamurugan, V. and Manoharan M. 2013. Cost and benefit of investment in integrated broiler farming - A case study. International Journal of current Research and Academic Review, 2(4): 114-123.

Borah, M. and Halim, R.A. 2017. Profitability Analysis of Broiler Farms: A case study of Sonitpur district of Assam. Economic Affairs. 62:23-32.

Chaterjee, R.N. and Rajkumar, U. 2015. An overview of poultry production in India. Indian journal of Animal Health, 54(2):89-108.

Patil, K.R., Chinnappa, B., Ganesh Prasad, K.P, Vishwajith , Manjunath, G.R. 2017. Economic performance of contract broiler farming. Indian Journal of Poultry Science, 57(2): 217-221.

Kumar, S. and Panigraphy, S.R. 2016. Farmers Perspective Towards Existing Poultry Contract Farming Model in Anand District of Gujurat. Economic Affairs, 61(4): 741-746.

Pawariya, V. and Jheeba, S.S. 2015. Economic analysis of costreturn, Income and employment in poultry enterprise in Jaipur district of Rajasthan state. International Journal of Agricultural Science and Research, 5(1): 73-80.

Shaikh, A.S. and Zala, Y.C. 2011. Production Performance and Economic Appraisal of Broiler Farms in Anand District of Gujarat. Agricultural Economics Research Review, 24: 317-323.

Shanmugham, T.R. Ranareddy, P. and Mohan B. 1997. Economics and financial analysis of broiler production in Kamarajar district of Tamil Nadu. International Journal of Animal Sciences, 12(1): 43-44.

Sharma, V., Grover, D.K. and Bawa, R.S. 1991. "Economics of Poultry Farming in Punjab". SARAS Journal of Livestock and Poultry Production, 7: 61-66.

Singh, Verinder Pal, Sharma, Shinde, V.K. and Kingra, H.S. 2010. Broiler production in Punjab-an economic analysis. Agriculture Economic Research Review, 23: 315-324. 